\title{
HIERARCHIZATION OF ABIOTIC ENVIRONMENTAL PROPERTIES - METHODICAL STUDY FOR RESEARCH ON THE ECOLOGY OF PLANTS IN PEAT BOG HABITATS
}

\author{
SERAFIN, A. ${ }^{1}$ - POGORZELEC, M. $^{2}$ - BRONOWICKA-MIELNICZUK, U. ${ }^{3 *}$ \\ ${ }^{I}$ Department of Environmental Engineering and Geodesy, University of Life Sciences in Lublin, \\ Leszczyńskiego 7, 20-069 Lublin, Poland \\ ${ }^{2}$ Department of Hydrobiology and Protection of Ecosystems, University of Life Sciences in \\ Lublin, Dobrzańskiego 37, 20-262 Lublin, Poland \\ ${ }^{3}$ Department of Applied Mathematics and Computer Science, University of Life Sciences in \\ Lublin, Gtęboka 28, 20-612 Lublin, Poland \\ *Corresponding author \\ e-mail: urszula.bronowicka@ up.lublin.pl; phone: +48-81-532-9626
}

(Received $1^{\text {st }}$ Dec 2018; accepted $18^{\text {th }}$ Feb 2019)

\begin{abstract}
The objective of this study was to perform the hierarchization procedure of habitat physicalchemical properties of peat bog waters in a five-year research cycle. The identification of important abiotic habitat properties in the context of the analyzed boreal plant relics' occurrence determines the mechanisms of their active protection, and in the case of useful plants with high medicinal values - the possibility of their ecological cultivation. The procedure covers desk studies involving source data analysis, field reconnaissance with selection of study sites, botanical-phytosociological analyses, and laboratory analyses of the abiotic properties of the habitat. The complex statistical analysis of the obtained data including descriptive statistics, non-parametric Kruskal-Wallis test, and multidimensional methods permitted the designation of range values for properties favoring the occurrence of the studied plant species. The procedure finds practical applications for both for the active protection of endangered plant species and other useful plants.
\end{abstract}

Keywords: boreal relic, herbs, peat bog, habitat, physical-chemical factors, research method

\section{Introduction}

Relevant literature quite frequently discusses the issue of conducting habitat research in the context of protection of rare plant species or importance of ecological conditions for proper growth and development of useful plants (e.g. Aleric and Kirkman, 2005; Zhang et al., 2002; Kostrakiewicz, 2008; Reckinger et al., 2010). Depending on the species, specificity of their biology and ecology, and the study objective, authors consider different environmental factors, from light conditions, temperature, and humidity (Matsumoto et al., 2000), through biogenic compounds (Wassen et al., 2005), to a combination of many largely varied environmental properties, which combined determine the quality of the habitat (Kumar and Stohlgren, 2009).

An example of a broad application of results of habitat research in reference to the key processes of the biology of a species threatened with extinction is the paper by Hroneš et al. (2018). The determination of the specificity of habitat conditions at the mountain sites of occurrence of the population of a rare relic species Salix lapponum in the Czech Karkonosze Mountains involved the application of results of research on both abiotic and biocoenotic environmental properties. First, floristic inventories performed in 207 study plots were analysed in terms of habitat preferences of all plant species, 
based on the ecological index numbers of vascular plants (Ellenberg et al., 1991). The following factors were considered: temperature, light, continentality, moisture, soil reaction, nutrients. The co-occurrence of plant species in the studied communities was also analysed. The next stage was the analysis of 207 soil samples in terms of basic soil properties, i.e. $\mathrm{pH}, \mathrm{N}\left(\mathrm{g} \cdot \mathrm{kg}^{-1}\right), \mathrm{P}\left(\mathrm{mg} \cdot \mathrm{kg}^{-1}\right), \mathrm{Ca}$, and $\mathrm{Mg}\left(\mathrm{mg} \cdot \mathrm{kg}^{-1}\right)$. The study results were compared to data concerning blooming or lack of blooming of individuals of the studied species. The authors initially evidenced differences in conditions occurring in microhabitats in which individuals bloom more frequently.

Data concerning abiotic environmental factors are also used for the purpose of improvement of the state of preservation of endangered plant species. Adhikari et al. (2012) designated a potential area and habitat for the reintroduction of Ilex khasiana Purk by means of the algorithm of modelling maximum entropy distribution (MaxEnt). The model was developed with the application of 16 data on the location in native range and 16 environmental parameters.

The analysis of results of habitat research by Nicolè et al. (2011) among others permitted answering the question in what way the dynamics of the population of the endangered high mountain plant Dracocephalum austriacum depends on the local quality of the habitat and climatic variability.

The reconstruction of habitats does not always permit the reintroduction to the environment of rare plant species. According to Kleijn et al. (2008), it may partially result from the inability to reconstruct the specific biogeochemical conditions preferred by such species. Many variables concerning habitat conditions have been evidenced to affect the condition of plants - in this case rare species of heathers in Holland, but it remains unknown what their relative importance is and whether any biogeochemical variable acts as the key factor limiting their maintenance.

Habitat research is also used for the analysis of the possibility of future cultivation of useful plants. The objective of the study by Sugier et al. (2011) was the determination of the content of phenol glycosides in the bark of dark-leaved willow (Salix myrsinifolia). The bark of the species was determined to be a potential source of salicylates, hence the proposal of introducing the species to cultivation. The study involved among others the determination of habitat conditions of natural functioning of the species. Characteristics of plant communities with a contribution of the studied species, and selected abiotic properties of the habitat were determined through the analysis of soil samples in terms of content of organic matter, macro- and microelements, and reaction.

The objective of this study is to present a developed complex procedure of hierarchization of abiotic habitat properties related to groundwaters of peat bog ecosystems of the Łęczna-Włodawa Lake District (Polesie Podlaskie, East Poland). The procedure was developed in reference to research concerning the specificity of occurrence of protected relic species - Salix lapponum, Salix myrtylloides, and Betula humilis (Serafin et al., 2015a, b, 2018a); and species of plants with medicinal properties, namely Menyanthes trifoliata and Oxycoccus palustris (Serafin et al., 2017, 2018b) at sites representative of the region where the measurements were performed (subjective assessment).

The identification of abiotic properties of the habitat important for the occurrence of these groups of plants, related to groundwaters, can provide the basis for the selection of the right strategy of active protection of endangered plant species, e.g. in the case of their reintroduction. It also allows for the determination of the conditions of potential ecological cultivation of peat bog plants with high useful potential, e.g. medicinal, in 
this case for naturotherapy - obtaining a natural composition of biologically active substances in cultivated herbal material (feature of natural medicine).

The popularisation of the procedure of hierarchization of abiotic habitat properties therefore seems to be a pragmatic measure.

\section{Methodological concept and practical application}

The developed procedure covers multiple-stage research: desk studies including the analysis of source texts; field reconnaissance for the selection of the right locations for conducting research, field research for botanical-habitat analyses at selected study sites, and laboratory analyses for the determination of the value of physical-chemical water parameters.

The applied statistical methods permit the interpretation of results and identification of factors important for the proper functioning of the studied plant species.

\section{Study sites and procedures}

Ecological analyses of different plant species require a complex approach to the selection of the study area. An optimal solution seems to be the determination of sites of occurrence of the studied species representative of a given region, characterised by the occurrence of its numerous populations in specific biocoenotic conditions, particularly in phytosociological terms. This is of particular importance in the case of research on natural conditions of occurrence of a given species. In nature, in spite of subjectively similar habitat conditions, largely undetermined factors exist that may affect the size of population of a given species in different ways. Subjective perception of the quality of habitats (including their apparent similarities) frequently does not consider factors determining the dynamics of the population of the studied species to a greater extent.

The variable size of population of the studied species at sites differing in terms of abiotic and biocoenotic factors in a given region permits the determination of the potential range of ecological tolerance of the species to the analysed environmental factors.

In the scope of the adopted assumptions and based on the conducted desk and field studies on peat bogs of the Lęczna-Włodawa Lake District, seven research locations representative of the region were selected (Fig. 1). They were lake-peat bog complexes - Bikcze (B), Karaśne (K), Moszne (M), Długie (D), Lubowierz (L), and ranges: Blizionki (BZ) and Dekowina (DK), covered by areal forms of nature protection particularly the Poleski National Park and its buffer zone (Fig. 1).

Research on habitat properties at the selected sites was applied in different configurations during the determination of the range of ecological valency of different plant species.

The verification of the accuracy of selection of study sites in reference to the preferences of a given plant species and naturalness of the occurring phytocoenoses was based on in situ botanical and phytosociological analyses.

In the scope of the adopted methodology, plant species inventories in selected locations of the Łęczna-Włodawa Lake District were performed still before the designation of particular study sites. The size of the eventually designated research plots was optimised, depending on specific conditions. The analysis of the naturalness of habitats was performed, e.g. based on the assignation of a specific plant species to 
historical-geographical and range groups, and determination of anthropogenic changes in the flora, articulated by the following ecological indices:
- total synanthropisation $-(\mathbf{W}$ s-c $)=\frac{A p+A}{S p+A} \times 100 \%$;
(Chmiel, 1993a)
- total anthropophytisation $-\left(\mathbf{W}_{\text {An-c }}\right)=\frac{A}{S p+A} \times 100 \%$
(Chmiel, 1993a)
- total apophytisation $-\left(\mathbf{W}_{\text {Ap-c }}\right)=\frac{A p}{S p+A} \times 100 \%$
(Chmiel, 1993a)

where $A p$ - apophytes (taxa of synantropic plants of local origin, constituting part of the native flora, occurring in anthropogenic habitats developed as a result of human activity; $S p$ - spontaneophytes (taxa developed in a given area or imported, able to function with no human interference, existing of nature) + apophytes, $A$ anthropophytes (taxa developed in a given area as a result of human pressure, taxa imported to a given area by man, and species surviving at sites under constant human pressure) devised by Chmiel (1993a, b).

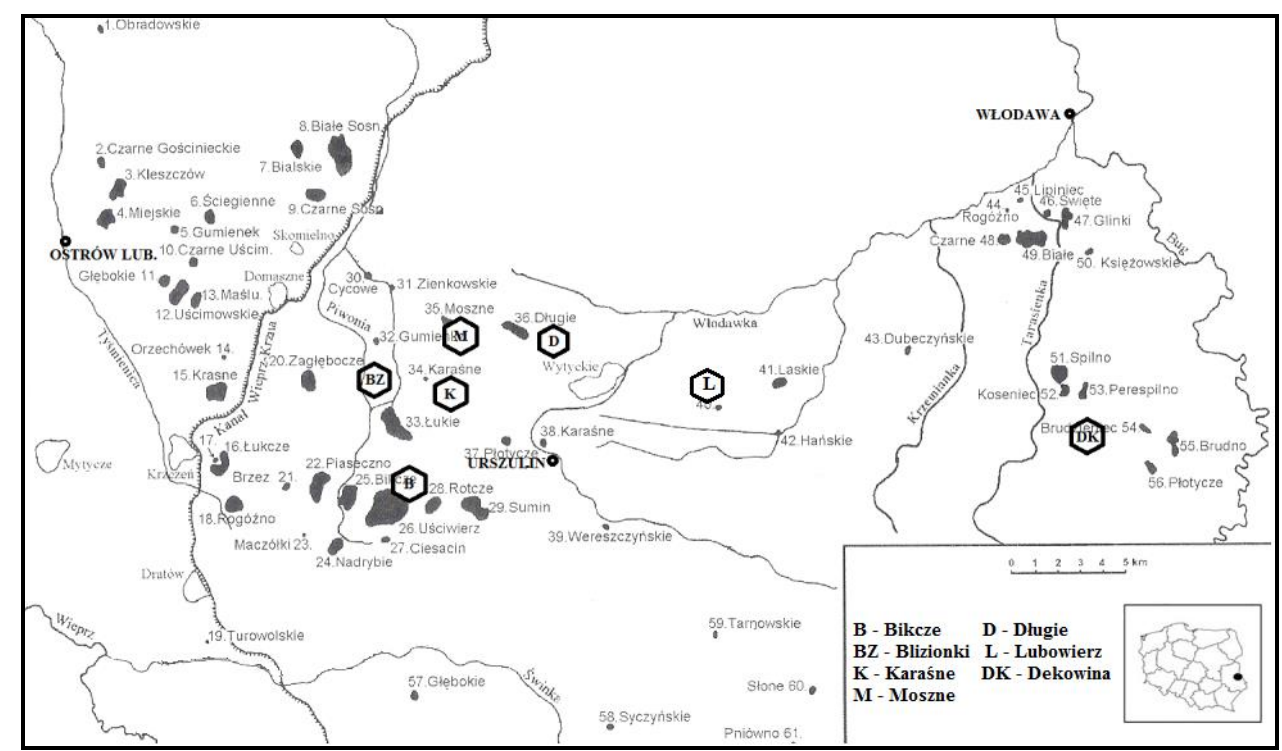

Figure 1. Location of study sites related to the method of hierarchization of abiotic habitat factors in the Lęczna-Włodawa Lake District (Harasimiuk et al., 1998, changed)

Low values of coefficients of anthropogenic changes in the flora suggest high biocoenotic naturalness of the selected locations, permitting the selection of specific study sites adjusted in terms of surface area to the local topographic and biocoenotic conditions, further described as subjectively representative (usually 100-625 $\mathrm{m}^{2}$ ).

The selected study sites were characterised by a variable abundance of populations of the studied taxa, which allowed for grouping them in terms of contribution (\%) of study objects in phytocoenoses.

Further analyses and presentation of results were performed for such designated groups. In the case of lack of considerable differences in the abundance of a given species in phytocoenoses of the selected sites, further analyses of all sites were performed for each site separately. Botanical research was supplemented with the 
following analyses: index of species similarity of phytocoenoses according to Jaccard (Piernik, 2008), and hierarchical classification, both for the sites, and for the species composition, and presented particularly in the form of tables (Table 1), dendrograms (Fig. 2), or their combinations with heatmaps (Fig. 3).

The aforementioned methods permitted a more thorough verification of the accuracy of selection of study sites in the context of species composition and phytosociological connections of peat bog habitats of selected locations. The final effect was the designation of groups of species of plants classified by frequency of occurrence at different study sites.

The determination of phytosociological affiliation of plants the most frequently accompanying the analysed objects permitted the final verification of the accuracy of selection of study sites in the scope of the adopted representative regional locations.

The next stage of research involved analyses of physical-chemical properties of peat bog waters. The selected factors covered the most important physical properties of waters: reaction $(\mathrm{pH})$, electrolytic conductivity (EC); biogenic chemical factors: phosphorus fractions - total phosphorus (TP), phosphates $\left(\mathrm{P}_{-} \mathrm{PO}_{4}\right)$, and nitrogen fractions - total nitrogen $(\mathrm{TN})$, ammonia nitrogen $\left(\mathrm{N}-\mathrm{NH}_{4}\right)$, nitrates $\left(\mathrm{N}-\mathrm{NO}_{3}\right)$, nitrites $\left(\mathrm{N}-\mathrm{NO}_{2}\right)$; content of dissolved organic carbon (DOC); sulphates $\left(\mathrm{S}-\mathrm{SO}_{4}\right)$, and selected ions: $\mathrm{Na}, \mathrm{K}, \mathrm{Ca}, \mathrm{Mg}$.

In order to perform such research, ground piezometers were dug in the central part of each site. They were perforated PVC pipes with a diameter of $0.1 \mathrm{~m}$ and length of $1 \mathrm{~m}$, ending in a cup closed with an adjusted lid.

Depending on the research schedule, water samples for further laboratory analyses, performed by means of certified methods, were collected from the peat bog piezometers with specified frequency.

Ranges of values of the analysed properties in comparison with the variable contribution of the studied species in phytocoenoses of selected sites determined the range of its ecological tolerance in reference to the analysed properties and region of its occurrence (Table 1; Fig. 4).

The study results were based on selected statistical methods and presented in graphic forms depicting the found patterns.

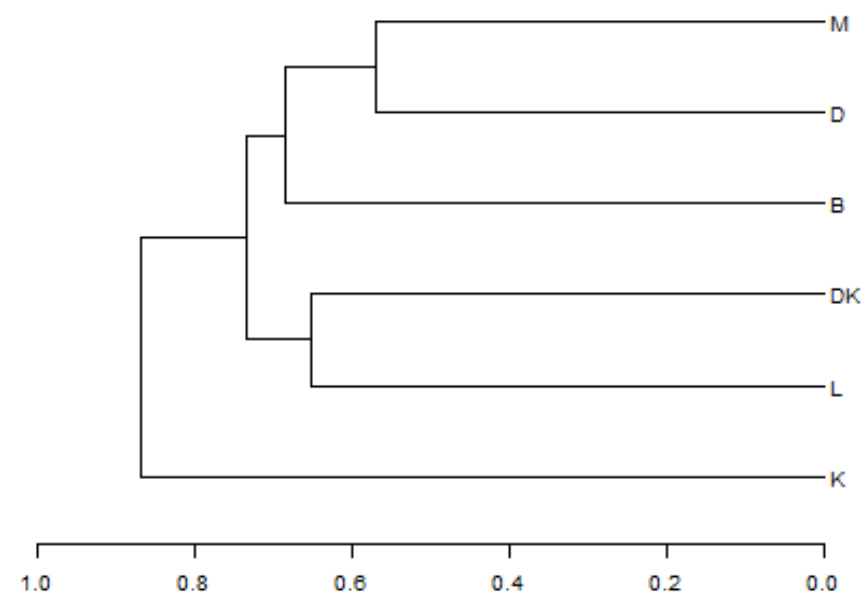

Figure 2. Dendrogram plot for sites as part of research on the occurrence of Betula humilis on the Eęczna-Wtodawa Lake Distict (Serafin et al., 2018a). M-Moszne, D - Dtugie, B - Bikcze, DK - Dekowina, L - Lubowierz, K-Karaśne 


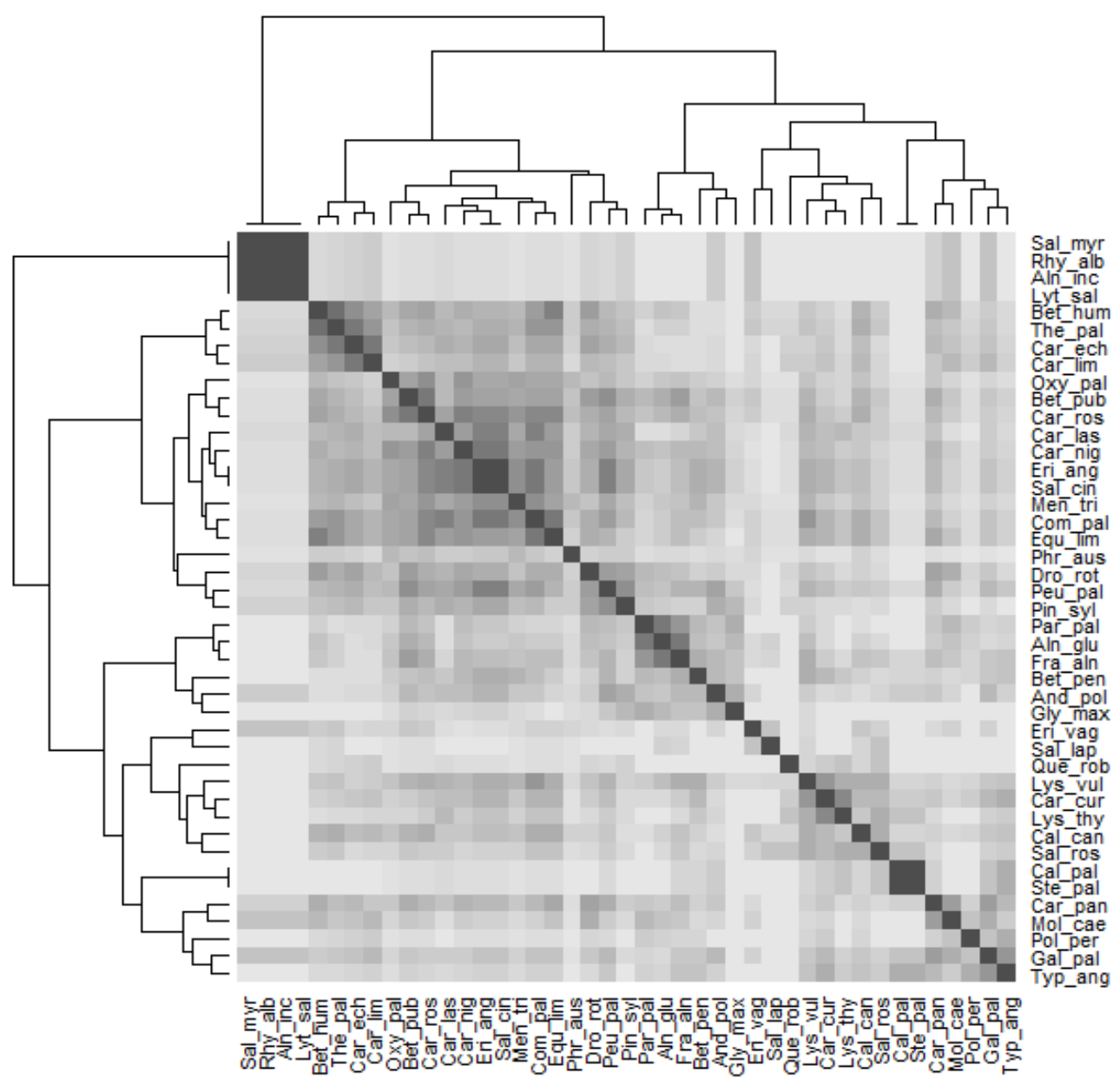

Figure 3. Dendrogram and heatmap of hierarchical cluster analysis of 43 species based on the Jaccard coefficient and Ward method as part of research related to the occurrence of Oxycoccus palustris in the Polesie Podlaskie Region (Serafin et al., 2018b). Species composition of phytocoenoses: Alnus glutinosa, Alnus incana, Andromeda polifolia, Betula humilis, Betula pendula, Betula pubescens, Calamagrostis canescens, Calla palustris, Carex curta, Carex echinata, Carex lasiocarpa, Carex limosa, Carex nigra, Carex panacea, Carex rostrata, Comarum palustre, Drosera rotundifolia, Equisetum limosum, Eriophorum angustifolium, Eriophorum vaginatum, Frangula alnus, Galium palustre, Glyceria maxima,

Lysimachia thyrsiflora, Lysimachia vulgaris, Lythrum salicaria, Menyanthes trifoliata, Molinia caerulea, Oxycoccus palustris, Quercus robur, Parnassia palustris, Peucedanum palustre,

Phragmites australis, Pinus sylvestris, Polygonum persicaria, Rhynchospora alba, Salix cinerea, Salix lapponum, Salix myrtilloides, Salix rosmarinifolia, Stellaria palustris, Thelypteris palustris, Typha angustifolia

Table 1. Values of the Jaccard similarity index between study sites related to the occurrence of Menyanthes trifoliata in peat bogs of Polesie Podlaskie Region (Serafin et. al. 2017) BBikcze, M-Moszne, K- Karaśne, D-Dtugie, BZ- Blizionki, DK-Dekowina

\begin{tabular}{c|c|c|c|c|c|c|c|c|c}
\hline B-M & 0.38 & M-D & 0.54 & D-K & 0.54 & K-BZ & 0.38 & BZ-DK & 0.33 \\
B-D & 0.51 & M-K & 0.52 & D-BZ & 0.41 & K-DK & 0.46 & & \\
B-K & 0.56 & M-BZ & 0.31 & D-DK & 0.46 & & & & \\
B-BZ & 0.34 & M-DK & 0.43 & & & & & & \\
B-DK & 0.46 & & & & & & & & \\
\hline
\end{tabular}



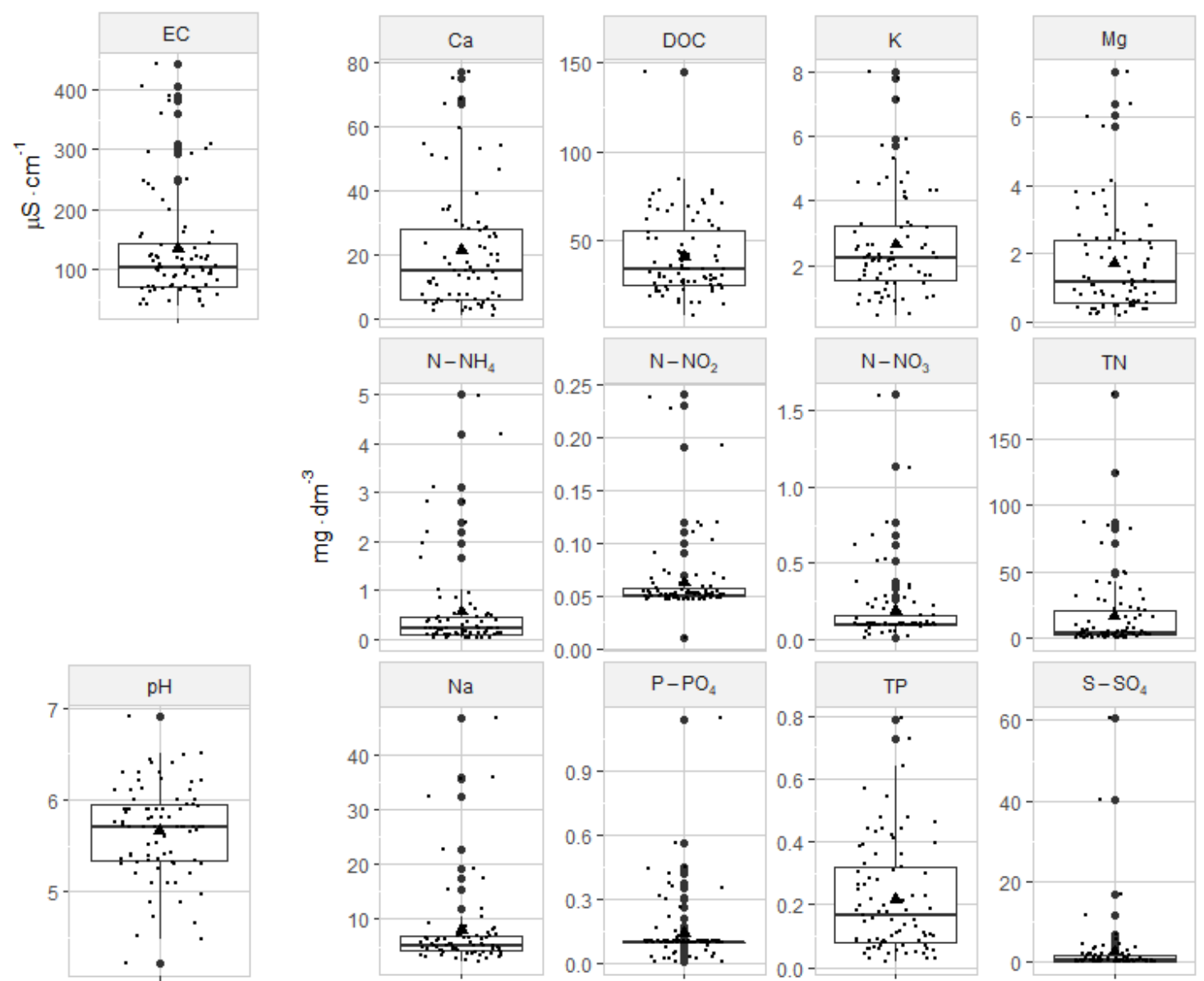

Figure 4. Distribution of values of the investigated physical-chemical properties of piezometric groundwater at the study sites in the period 2011-2014 for occurrence of Betula humilis on the

Polesie Podlaskie peat bogs (Serafin et al., 2018a). (The box-and-whisker plots show the distribution of observations. In particular, the box represents the first and third quartiles. The horizontal line across the central region of the box represents the median. The mean value of the data is marked by a filled triangle. The whiskers are drawn to the most extreme observations that are located no more than 1.5 times the inter quartile range away from the box. Any observation not included between the whiskers is considered as an outlier and is plotted with an filled circle. When there are no outliers, the whiskers indicate the minimum and maximum values. The plot presents observed values of particular parameters, marked with small dots)

\section{Statistical methods}

The statistical analysis of the species composition of the analysed phytocoenoses and values of physical-chemical properties of peat bog waters was divided into several stages.

The first stage concerning the analysis of the species composition of phytocoenoses at the study sites employed multidimensional methods, applied for distinguishing from the studied locations groups of objects uniform in terms of species composition (cluster analysis). Cluster analysis is a multidimensional technique permitting detecting similarities between analysed objects. Detection of similarities of sites in terms of species composition involved the application of the procedure of agglomerative hierarchical classification (Borcard et al., 2011). The practical and frequently applied in 
similar analyses Jaccard coefficient (Piernik, 2008) was adopted as the measure of similarity. The key element of the analysis, affecting the results of grouping, is the choice of the grouping procedure. In spite of a high number of publications concerning the issues (among others Sneath and Sokal, 1973; Jongman et al., 1995; Legendre and Legendre, 1998; Digby and Kempton, 2014), no universal algorithm of selection of the method of grouping of data exists. The final selection is usually determined by obtaining interpretable clusters. In the case of research employing the hierarchization procedure, the algorithm of minimum variance (Ward clustering) proved the most efficient for the species composition, as well as the algorithm of complete linkage for habitats (Serafin et al., 2015a, 2018a, b). The obtained results of the classification were presented graphically in the form of a dendrogram (diagram of another connection of objects - sites or species - in clusters together with distances for the connections) or heatmaps (intensity of colour representing among others differences in the frequency of joint occurrence) - compare Figure 3.

The next stage involved the statistical analysis of the structure of distribution of values of abiotic properties of a habitat for particular sites. Methods of descriptive statistics were applied for this purpose. Basic measures of distribution were determined for physical-chemical water properties. Additionally, the most important position statistics were presented in the form of boxplots - compare Figure 4. The analysis of the diagrams permitted the assessment of data distribution, identification of potential distribution skewness, and observations of untypical data or data suspected of untypical character. Then, the distribution of the analysed factors was performed for particular sites (or selected groups of sites with similarly higher and similarly lower \% contribution of the analysed species). Due to the rejection of hypotheses on normality of distribution and homogeneity of variance, the comparison employed a non-parametric Kruskal-Wallis test.

A more thorough analysis of dependencies in the data set including the species composition of the analysed phytocoenoses (species composition) and physicalchemical properties of peat bog waters (environmental variables) at particular sites was possible with the application of the multidimensional direct ordination method (Jongman et al., 1995). The most popular methods of the type include redundancy analysis (RDA) and canonical correspondence analysis (CCA). The selection of the appropriate method was done based on the value of the length of the ecological gradient obtained by means of detrended correspondence analysis (DCA) (Gauch, 1982). DCA is indirect ordination method, and is performed based on data on species composition. In the discussed study, the length of the ecological gradient showed that the structure of the analysed data is of linear character (Jongman et al., 1995). Therefore, a method suitable for further research was the redundancy analysis (RDA). Before performing the analysis, for the purpose of meeting the assumption on normality, relevant transformation of data on environmental variables and their standardisation is required (Legendre and Legendre, 1998; Borcard et al., 2011). In the case of data on species, the necessity of their transformation was also considered (Legendre and Gallagher, 2001).

Prior to the analysis, redundant environmental variables (with linear correlation coefficient $|\mathrm{r}|>0.6$ ) were omitted to avoid collinear rite (Blanchet et al., 2008). The RDA output was presented graphically in the form of a triplot where sites and particular species are presented as points, and environmental variables as arrows. In the case of analyses performed with the application of the vegan package (Oksanen et al., 2018), in environment R (2017), depending on the used scaling method (scaling 1 or scaling 2), it 
was possible to obtain two types of triplots (compare Fig. 5). The selection of the scaling method determined the interpretation of the obtained triplot. The triplot obtained for scaling 1, also called a distance triplot, permitted the analysis of dependencies in the context of Euclidean distances among objects. In the case of scaling 2, it is the so-called correlation triplot, where the primary goal was the assessment of the occurring correlations for environmental variables. A detailed interpretation of triplots for both scaling types was performed based on Legendre and Legendre (1998).

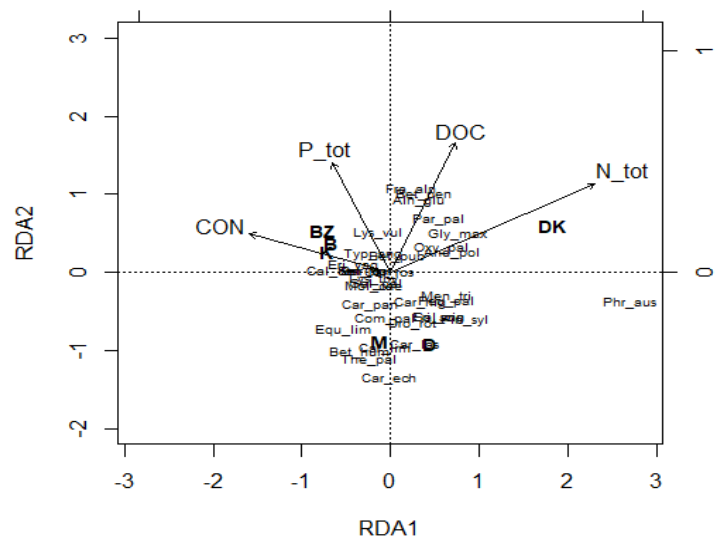

(a) scaling $=1$

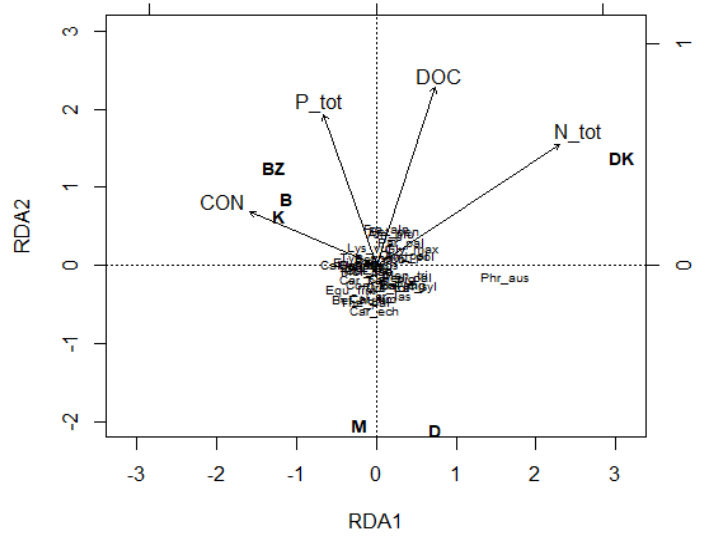

(b) scaling $=2$

Figure 5. Triplot of RDA with fitted site scores, species and environmental variables as arrows connected with occurrence of Oxycoccus palustris in the Polesie Podlaskie Region (Serafin et al., 2018b)

In the case of analysis aimed at the detection of the structure and general patterns between the analysed physical-chemical water parameters at specific sites, indirect ordination methods should be applied. The performance of this type of analyses employed one of the oldest and most frequently applied methods, namely principal component analysis (PCA). The method was indicated by the length of the ecological gradient as suitable for the investigation of mutual relations of environmental data of the study area, irrespective if the species composition of the analysed biocoenoses, in the case of analysis of occurrence of relic species of willows (Serafin et al., 2015a, b). The PCA output was presented as a biplot where objects (sites) are presented a points, and environmental variables as arrows (Fig. 6). Similarly as in the case of RDA, the interpretation of biplots also depends on the selected scaling method (Legendre and Legendre, 1998).

\section{Possibilities of interpreting results}

Based on the performed procedure, competent study results were obtained permitting the following for particular plant species: 1) identification of representative study sites related to the preferences of species, analysis of association of the accompanying plants, and degree of naturalness of habitats; 2) estimation of the range of ecological tolerance in reference to the analysed habitat properties and region of occurrence of study objects, and 3) determination of statistically significant abiotic factors favouring the occurrence of their populations, and sometimes also ranges of values of the factors. 


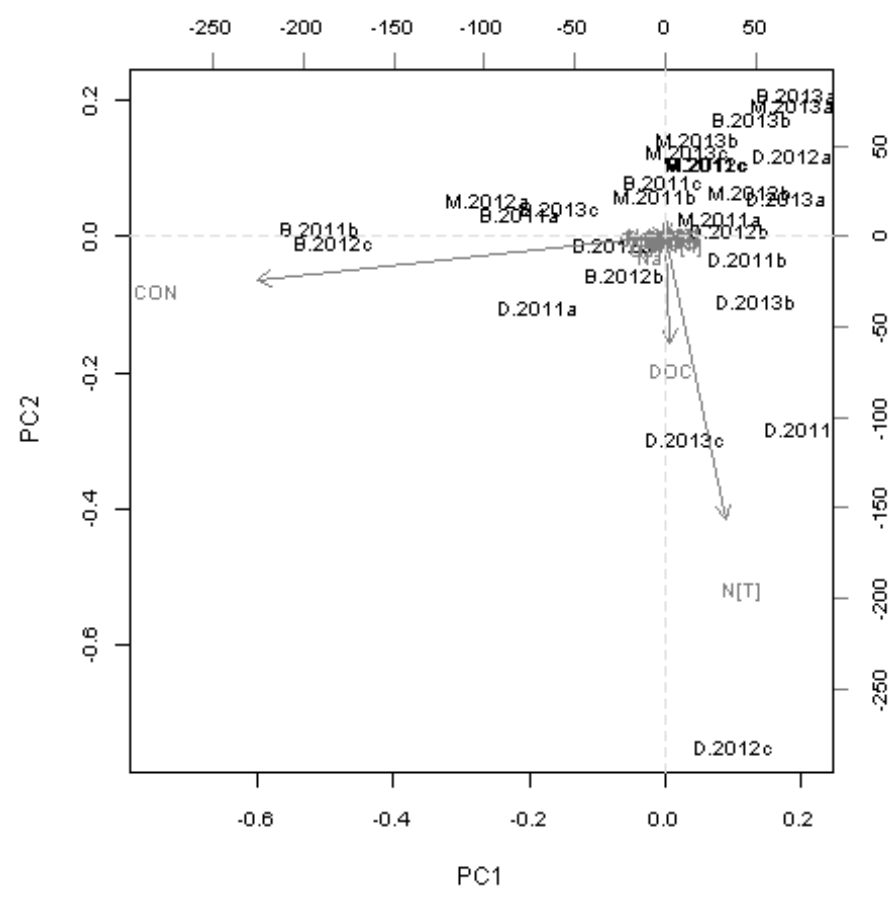

Figure 6. Projection of the original 14-dimensional scores onto the first two principal components for occurrence of Salix myrtilloides on the Polesie Podlaskie peat bogs (Serafin et al., 2015b). (The black labels indicate individual data items. Each variable (factor) is represented as a vector, while the direction and the length of the vector indicate how the corresponding variable contributes to a principal component)

Study sites were designated for all plant species considered in the study in selected locations representative of the region. Their naturalness was evidenced by botanicalphytosociological analyses confirming the presence of plants from classes: Scheuchzerio-Caricetea, Alnetea glutinosae, and Oxycocco-Sphagnetea in the species composition of the analysed phytocoenoses strongly related to ombrogenic habitats of raised and transitional bogs, optimal in terms of occurrence of the analysed plant species (Serafin et al., 2017; Serafin et al., 2018a, b). Low values of anthropogenic coefficients of changes in the flora, high Jaccard coefficient indices, statistical hierarchical analysis of species similarity, as well as multidimensional analyses of the frequency of occurrence of characteristic species associations determined by preferences of the studied species additionally confirmed the accuracy of selection of natural study sites.

The specificity of occurrence of the studied species in reference to characteristic features of the peat bog environment in the region of Polesie Podlaskie (East Poland) permitted the determination that both boreal relics and medicinal plant species were characterised by a relatively broad amplitude of values of the majority of the studied physical-chemical properties of peat bog waters. This probably constitutes proof of the broad range of their ecological tolerance in reference to such factors and to such regional locations. The distribution of values of some of the analysed properties was favourable for the maintenance of the populations of the analysed species, whereas the distribution of the remaining ones should be considered as neutral or unfavourable. In the case of Salix myrtilloides, low level of values of nitrogen fractions, phosphorus fractions, studied cations, and DOC can be considered a group of conditions favouring 
the functioning of its population (Serafin et al., 2015b), whereas for the simultaneously studied Salix lapponum, such conditions were met by: low level of TN, phosphorus fractions and DOC, as well as a high level of $\mathrm{Ca}, \mathrm{pH}$, and EC (Serafin et al., 2015a).

For Betula humilis, values of statistically significant, favourable for its occurrence abiotic properties of groundwaters were provided in more detail also providing ranges of their values based on boxplots for which the upper and lower quartile referred to the Kruskal-Wallis test provide information on the range of values of physical-chemical water properties significant for the species. They included: TP: 0.08-0.32; P-PO $\mathrm{PO}_{4}$ 0.1; TN: 2.2-21.2; N-NH4: 0.1-0.46; DOC: $24.6-56.9\left(\mathrm{mg} \cdot \mathrm{dm}^{-3}\right)$, as well as higher than average $\mathrm{pH}$ values, in a range of: 5.34-5.95; Ca: 5.67-28.1; $\mathrm{Mg}: 0.56-2.41\left(\mathrm{mg} \cdot \mathrm{dm}^{-3}\right) \mathrm{m}$ and $\mathrm{EC}$ in $\mu \mathrm{S} \cdot \mathrm{cm}^{-1}:$ 72.1-142.3 (Serafin et al., 2018a).

For species of herbal plants with perspective possibility of ecological cultivation, additional research is necessary concerning the natural content of biologically active substances at natural sites of their occurrence (currently conducted). Nonetheless, also in their case, complexes of factors favouring their more abundant occurrence were determined.

For Menyanthes trifoliata they were - TN $\left(\mathrm{N}_{\text {total }}\right)$ : from 4.16 to 27.4 , $\mathrm{TP}\left(\mathrm{P}_{\text {total }}\right)$ from 0.93 to $0.14\left(\mathrm{mg} \cdot \mathrm{dm}^{-3}\right)$, EC (conductivity) from 70.4 to $112 \mu \mathrm{S} \cdot \mathrm{cm}^{-1}$, and $\mathrm{pH}$ from 5.23 to 5.55 (compare Fig. 7).

Lower concentration values of important habitat parameters in the following ranges: $\mathrm{TP}=0.17-0.36 ; \mathrm{P}^{-} \mathrm{PO}_{4}=0.1$, and $\mathrm{DOC}=33.81-55.90\left(\mathrm{mg} \cdot \mathrm{dm}^{-3}\right)$ can be considered as a state favouring proper functioning of Oxycoccus palustris individuals (Serafin et al., 2018b). Parameters important for the occurrence of a population of Comarum palustre in Polesie Podlaskie included: $\mathrm{N}_{-} \mathrm{NH}_{4}, \mathrm{Ca}, \mathrm{Mg}, \mathrm{DOC}, \mathrm{EC}$, and $\mathrm{pH}$ (Serafin et al., in review).

The summary of the applied procedure of hierarchization of abiotic habitat properties in botanical research were PCA and RDA analyses supplementing the dependencies between groups of the studied elements: species composition of phytocoenoses, species similarity of study sites, and the values of physical-chemical properties of peat bog waters at the sites.

For example, in the case of Salix lapponum, the application of PCA analysis showed the highest correlations between chemical variables such as: $\mathrm{P}_{-} \mathrm{PO}_{4}-\mathrm{TP}(0.9421), \mathrm{N}-$ $\mathrm{NH}_{4}-\mathrm{TN}(0.7607)$, and EC-pH (0.7533). It was also determined that EC, Ca, and $\mathrm{pH}$ were higher at site Karaśne (K) in comparison to sites Blizionki (BZ) and Lubowierz (L), and values of phosphorus fractions were higher for BZ in comparison to sites $\mathrm{K}$ and $\mathrm{L}$, and that the separation of clusters $\mathrm{K}$ and $\mathrm{L}$ particularly results from the contribution of $\mathrm{EC}, \mathrm{Ca}, \mathrm{pH}, \mathrm{N}-\mathrm{NH}_{4}, \mathrm{TN}$, and DOC. Some data from sites B and $\mathrm{L}$ showed more uniform structure (Serafin et al., 2015a).

The analysis of data from research concerning Oxycoccus palustris based on the RDA method suggests that study sites located closer to each other (such as B, K, BZ, as well as D, M) have a similar species composition and similar values of habitat variables. Sites B, K, and BZ are characterised by high levels of EC and TP. Variable TN was related to the positive part of axis 1, and EC occupies the opposite part of the axis. The second axis is positively correlated with DOC and TP. The triplot suggests a positive correlation between TN and DOC, as well as a similar correlation of values between EC and TP, as well as between TP and DOC. In terms of species-habitat dependencies, the studied species was observed to be strongly positively correlated with TN (Serafin et al., 2018b). 

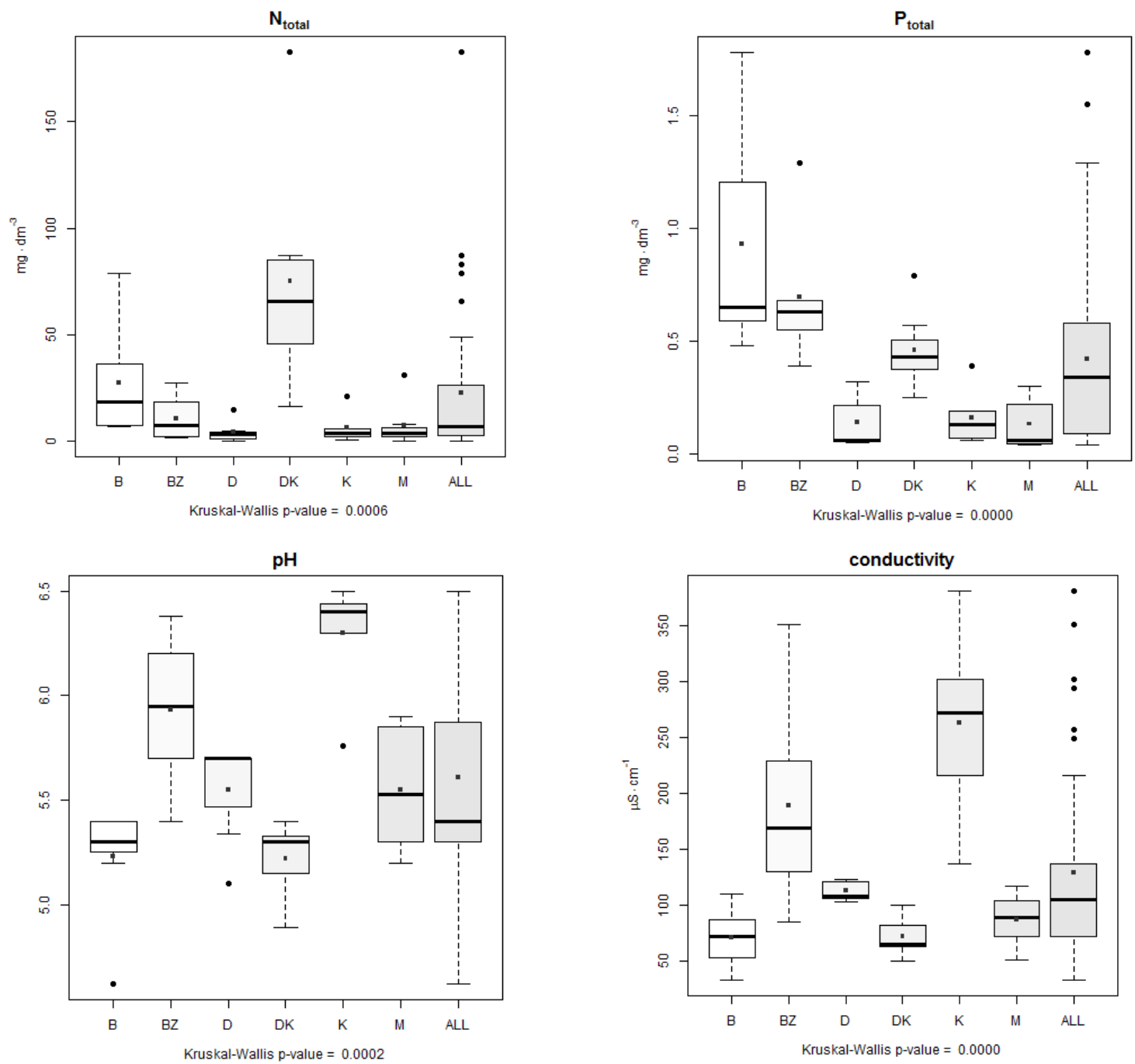

Figure 7. Distribution of values of the investigated chemical factors of piezometric groundwater at the study sites in the period 2011-2013 (Serafin et al., 2017). (The box-and-whisker plots show the distribution of observations. The bottom and top of the box indicate the first and the third quartiles, respectively. The horizontal line across the central region of the box represents the median. The mean value of the data is marked by a filled square. The whiskers are drawn to the most extreme observations that are located no more than 1.5 times the inter quartile range away from the box. Any observation not included between the whiskers is plotted as an outlier with an circle. When there are no outliers, the whiskers indicate the minimum and maximum values. The abbreviations of the selected study sites are used to label tick marks on the $x$ horizontal axis. The $x$ axis label provides the p-value derived from the Kruskal-Wallis test)

\section{Summary and conclusions}

The modern dynamics of ecological patterns of different ecosystems require complex research methods accompanying the course of selected ecological phenomena and processes. Unlike in the case of comparative and reconstruction research, it is usually long-term, stationary research (in selected locations), also called process accompanying research. After a certain time, it provides material for many scientific fields, constituting the basis of essential source texts used in the planning and implementation of various research. In the case of the field of science based on botanical ecological analyses - 
dynamics of vegetation also called syndynamics - the basis for practical research methods was provided by among others Braun-Blanquet (1922); Collier et al. (1973, 1978); Faliński (1986); Burrows (1990); or Dierschke (1994). Irrespective of the character of the performed analyses, their success usually depends on three factors: consistency of interest, selection of the object, and continuity of financing (Faliński, 2001).

The procedure of hierarchization of abiotic habitat properties for botanical analyses in natural peat bog conditions meets all three conditions. It is based on constant interest in the study issue - particularly the occurrence of boreal relics in natural, although subject to increasing human pressure (global - climate change, and regional - impact of the Lublin Coal Basin, effect of the Melioration System if the Wieprz-Krzna Channel, as well as tourism and recreation in the Łęczna-Włodawa Lake District) habitats of Polesie Podlaskie (East Poland). Supplementary botanical research also focused on the conditions of occurrence of valuable species of herbal plants, and those with a perspective of ecological cultivation.

The selection of study objects resulted from conscious scientific interest of the authors particularly concerning boreal species of willows: Salix lapponum and Salix myrtilloides, subject to research already from the early 2000's (e.g. Pogorzelec, 2008, 2009). In the case of selected species of herbs: Menyanthes trifoliata, Oxycoccus palustris, and Comarum palustre, further research concerning the composition of biologically active substances in herbal material is currently conducted for different sites, and their occurrence in the aspect of performing an experiment of their ecological cultivation.

Eventually, financing of the said research was on the one hand related to resources available in the scope of project of NCN No. NN304385239: Population ecology and active protection of boreal relics from the Salicaceae (Salix lapponum and Salix myrtylloides) in Polesie Lubelskie Region, under the direction of D. Ph. Magdalena Pogorzelec, implemented in the years 2010-2014, and on the other hand to the statutory activity of the Department of General Ecology University of Life Science In Lublin (Poland), where Ph. D. Artur Serafin and Ph. D. Magdalena Pogorzelec were employed at the time.

The primary effect of the developed procedure are the possibilities of its practical application. In the scope of the restitution of the said species of willow in Polesie Podlaskie based on a project entitled: Active protection of particularly endangered species of relic plants from family Salicaceae in peat bog habitats (supervision Ph. D. Magdalena Pogorzelec), measures of their active protection have been implemented since 2018, involving their reintroduction. Places of introduction of new individuals of both species obtained from ex situ cultivation were optimised as habitats in terms of values of the analysed physical-chemical properties of peat bog waters in accordance with results of research based on the procedure described above.

In the case of the studied herbs, the perspective of their ecological cultivation depends on solving several issues. Firstly, in natural conditions of peat bogs, obtaining herbal material faces difficulties concerning the terrain conditions and safety of persons collecting plants. Secondly, part of herbal species are under species protection, and their collection is treated as an offence (Menyanthes trifoliata). Thirdly, the most natural habitats of occurrence of the plants are located in areas subject to different forms of areal protection (e.g. national park, landscape park, nature reserve, or ecological grounds), therefore sanctioning the possibility of collection of any plants in different 
ways. Finally, as a result of hydrotechnical economy, peat bog ecosystems are subject to shrinking in the territory of the majority of European countries (Ilnicki, 2002), resulting in a real threat of extinction of many species of plants related to this type of habitats. Ecological cultivation of medicinal species in optimal conditions of their natural occurrence provides a solution to the aforementioned problems. A very important issue in this aspect is the search for natural compositions of biologically active substances in herbal material for the purpose of development of a natural herbal medicine in accordance with the rules of the Good Manufacturing Practice (GMP) pursuant to the guidelines of the WHO (Borkowski, 1994; Drozd, 2012). It is particularly important in the times of search for different elements and measures limiting environmental impact and important for human health, especially in the context of naturotherapy, constituting a desirable alternative to synthetic pharmacology and dangerous polypharmacy (Oliveira et al., 2012; Senderski, 2015; Serafin et al., 2018b). Currently conducted research employing the procedure of hierarchization of abiotic properties of habitats for studied herb species preliminarily confirms higher values of biologically active substances from locations characterised by optimised natural values of the analysed physical-chemical water properties (Serafin, Dzida, unpublished data).

Due to the above, the developed procedure finds practical application both for active protection of endangered plant species and in the case of useful plants.

\section{REFERENCES}

[1] Adhikari, D., Barik, S. K., Upadhaya, K. (2012): Habitat distribution modelling for reintroduction of Ilex khasiana Purk., a critically endangered tree species of northeastern India. - Ecological Engineering 40: 37-43.

[2] Aleric, K. M., Katherine Kirkman, L. (2005): Growth and photosynthetic responses of the federally endangered shrub, Lindera melissifolia (Lauraceae), to varied light environments. - American Journal of Botany 92(4): 682-689.

[3] Blanchet, F. G., Legendre, P., Borcard, D. (2008): Forward selection of explanatory variables. - Ecology 89: 2623-2632. DOI: 10.1890/07-0986.1.

[4] Borcard, D., Gillet, F., Legendre, P. (2011): Numerical Ecology with R. - Springer, New York. DOI: 10.1007/978-1-4419-7976-6.

[5] Borkowski, B. (1994): Rośliny lecznicze w fitoterapii. - Instytut Roślin i Przetworów Zielarskich, Poznań.

[6] Braun-Blanquet, J. Pavillard, J. (1922): Vocabulaire de Sociologie Végétale. Montpellier.

[7] Burrows, C. J. (1990): Processes of Vegetation Change. - Unvin Hyman, London.

[8] Chmiel, J. (1993a): Flora roślin naczyniowych wschodniej części Pojezierza Gnieźnieńskiego i jego antropogeniczne przeobrażenia w wieku XIX i XX. Część I i II. Pr. Zakł. Taksonomii Roślin UAM w Poznaniu 1: 1-201.

[9] Chmiel, J. (1993b): Flora roślin naczyniowych wschodniej części Pojezierza Gnieźnieńskiego i jego antropogeniczne przeobrażenia w wieku XIX i XX. Część I i II. Pr. Zakł. Taksonomii Roślin UAM w Poznaniu 2: 1-212.

[10] Collier, B. D., Cox, G. W., Johnson, A. W., Miller, P. C. (1973): Dynamic Ecology. California State University, San Diego.

[11] Collier, B. D., Cox, G. W., Johnson, A. W., Miller, P. C. (1978): Ekologia dynamiczna. PWRiL, Warszawa.

[12] Dierschke, H. (1994): Pflanzensoziologie. Grundlagen und Methoden. - Ulmer, Stuttgart.

[13] Digby, P. G. N., Kempton, R. A. (2014): Multivariate analysis of ecological communities. - Chapman and Hall, London. DOI: 10.1007/978-94-009-3135-0. 
[14] Drozd, J. (2012): Wczoraj i dziś - ziołolecznictwa. - Przegląd Medyczny Uniwersytetu Rzeszowskiego i Narodowego Instytutu Leków w Warszawie. Rzeszów, pp: 245-251.

[15] Ellenberg, H., Weber, H., Düll, R., Wirth, V., Werner, W., Paulissen, D. (1991): Zeigerwerte der Gefässpflanzen in Mitteleuropa. Scripta Geobot. 18. - Verlag Erich Goltze, Göttingen.

[16] Faliński, J. B. (1986): Vegetation dynamics in temperate lowland primeval forests. Ecological studies in Białowieża Forest. - Dr W. Junk Publishers, Dordrecht/Boston/Lancaster.

[17] Faliński, J. B. (2001): Przewodnik do długoterminowych badań ekologicznych. - Wyd. Naukowe PWN, Warszawa.

[18] Gauch, H. G. (1982): Multivariate Analysis in Community Ecology. - Cambridge University Press, Cambridge, UK.

[19] Harasimiuk, M., Michalczyk, Z., Turczyński, M. (1998): Jeziora ŁęczyńskoWłodawskie. - Biblioteka Monitoringu Srodowiska, Lublin, Poland.

[20] Hroneš, M., Hrachová, Macurová, S., Hradílek, Z., Duchoslav, M. (2018): Habitat conditions, stage structure and vegetation associations of geographically isolated subalpine populations of Salix lapponum L. (Salicaceae) in the Krkonoše Mts (Czech Republic). - Biologia 73(4). DOI: 10.2478/s11756-018-0051-4.

[21] Ilnicki, P. (2002): Torfowiska i torf. - Wyd. Akademii Rolniczej im. Augusta Cieszkowskiego w Poznaniu, Poznań.

[22] Jongman, R. H. G., Ter Braak, C. J. F., Van Tongeren, O. F. R. (1995): Data Analysis in Community and Landscape Ecology. - Cambridge University Press, New York, USA.

[23] Kleijn, D., Bekker, R. M., Bobbink, R., De Graaf, M. C., Roelofs, J. G. (2008): In search for key biogeochemical factors affecting plant species persistence in heathland and acidic grasslands: a comparison of common and rare species. - Journal of Applied Ecology 45(2): 680-687.

[24] Kostrakiewicz, K. (2008): Population structure of a clonal endangered plant species Iris sibirica L. in different habitat conditions. - Pol. J. Ecol 56(4): 581-592.

[25] Kumar, S., Stohlgren, T. J. (2009): Maxent modeling for predicting suitable habitat for threatened and endangered tree Canacomyrica monticola in New Caledonia. - Journal of Ecology and the Natural Environment 1(4): 094-098.

[26] Legendre, P., Gallagher, E. D. (2001): Ecologically meaningful transformations for ordination of species data. - Oecologia 129: 271-280. DOI: 10.1007/s004420100716.

[27] Legendre, P., Legendre, L. (1998): Numerical Ecology. 2nd Ed. - Elsevier, Amsterdam.

[28] Matsumoto, J., Muraoka, H., Washitani, I. (2000): Whole plant carbon gain of an endangered herbaceous species Aster kantoensis and the influence of shading by an alien grass Eragrostis curvula in its gravelly floodplain habitat. - Annals of Botany 86(4): 787797.

[29] Nicolè, F., Dahlgren, J. P., Vivat, A., Till-Bottraud, I., Ehrlén, J. (2011): Interdependent effects of habitat quality and climate on population growth of an endangered plant. Journal of Ecology 99(5): 1211-1218.

[30] Oksanen, J., Blanchet, F. G., Friendly, M. (2018): Vegan: Community Ecology Package. - R package version 2.5-2.

[31] Oliveira, S. G. D., De Moura, F. R. R., Demarco, F. F., Da Silva Nascente, P., Del Pino, F. A. B., Lund, R. G. (2012): An ethnomedicinal survey on phytotherapy with professionals and patients from Basic Care Units in the Brazilian Unified Health System. - Journal of Ethnopharmacology 140(2): 428-437.

[32] Piernik, A. (2008): Metody numeryczne w ekologii. - Wyd. UMK, Toruń.

[33] Pogorzelec, M. (2008): Influence of chosen environmental abiotic factors on Salix lapponum L. populations functioning in Polesie Lubelskie Region. - Polish J. of Environ. Stud. 17(4): 139-144.

[34] Pogorzelec, M. (2009): The downy willow (Salix lapponum L.) as a component of different phytocoenosis in Poleski National Park. - Acta Agrobotanica 62(1): 107-116. 
[35] R Core Team (2017): R: R Foundation for Statistical Computing. - R Core, Vienna.

[36] Reckinger, C., Colling, G., Matthies, D. (2010): Restoring populations of the endangered plant Scorzonera humilis: influence of site conditions, seed source, and plant stage. Restoration Ecology 18(6): 904-913.

[37] Senderski, M. E. (2015): Prawie wszystko o ziołach i ziołolecznictwie. - Wyd. własne, Podkowa Leśna.

[38] Serafin, A., Pogorzelec, M., Banach, B., Mielniczuk, J. (2015a): Physico-chemical groundwater conditions at Salix lapponum stands in Eastern Poland. - Dendrobiology 73: 65-74. DOI: 10.12657/denbio.073.007.

[39] Serafin, A., Pogorzelec, M., Banach, B., Mielniczuk, J. (2015b): Habitat conditions of the endangered species Salix myrtilloides in Eastern Poland. - Dendrobiology 73: 55-64. DOI: 10.12657/denbio.073.006.

[40] Serafin, A., Pogorzelec, M., Bronowicka-Mielniczuk, U. (2017): The specificity of natural habitats of Menyanthes trifoliata L. in the peat bogs of the central parts of eastern Poland. - Applied Ecology and Environmental Research 15(3): 849-859.

[41] Serafin, A., Urban, D., Bronowicka-Mielniczuk, U., Szczurowska, A. (2018a): To what degree can the specifics of occurrence of glacial relic Betula humilis Schrank be an indicator of habitat conditions of moderate climate peatlands? - Water (Switzerland). DOI: $10.3390 /$ w 10081062 .

[42] Serafin, A., Pogorzelec, M., Bronowicka-Mielniczuk, U. (2018b): Habitat preferences of Oxycoccus palustris Prs. on peat bogs in east Poland in the perspective of shaping the conditions of ecological cultivation of the species. - Applied Ecology and Environmental Research. DOI: 10.15666/aeer/1604_40154028.

[43] Sneath, P., Sokal, R. (1973): Numerical Taxonomy. The Principles and Practice of Numerical Classification. - Freeman, San Francisco.

[44] Sugier, D., Sugier, P., Pawełek, M., Gawlik-Dziki, U. (2011): Salix myrsinifolia Salisb. as a source of phenolic glycosides: distribution and characteristic of habitat conditions in the mid-eastern Poland. - Acta Scientiarum Polonorum, Hortorum Cultus 10(3): 75-88.

[45] Wassen, M. J., Venterink, H. O., Lapshina, E. D., \& Tanneberger, F. (2005): Endangered plants persist under phosphorus limitation. - Nature 437(7058): 547.

[46] Zhang, W., Zu, Y., Liu, G. (2002): Population ecological characteristics and analysis on endangered cause of ten endangered plant species. - Acta Ecologica Sinica 22(9): 15121520 . 